\title{
URGENSI DAN KONTRIBUSI SOSIOLINGUISTIK DALAM LINGUISTIK EDUKASIONAL
}

\author{
Mamluatul Hasanah \\ Dosen Jurusan Bahasa dan Sastra Arab, \\ Fakultas Humaniora dan Budaya, Universitas Islam Negeri (UIN) Malang. \\ Jalan Gajayana No. 50 Telepon (0341) 570872, Faksimile (0341) 570872 Malang 65144
}

\begin{abstract}
Language learning deals with the concept of language truth, language teaching, language teacher, and language context. Sociolinguistics is one of the applied linguistics which answers to the questions of language in society and also language context. Thus, sociolinguistics has great contribution on language learning especially relating with the language policy and the choise of appropriate textbook which is suitable with the social context of language learner.
\end{abstract}

\section{Key words}

Sosiolinguistics, Language Learning, Teaching

\section{Pendahuluan}

Sosiolinguistik sebagai ilmu yang dianggap baru menuntut kehadirannya sejajar dengan ilmu-ilmu lain. Beitu juga, sosiolinguistik menuntut keikutsertaannya dalam memberikan informasi dalam pengambilan kebijakan-kebijakan kebahasaan, termasuk kebijakan kebahasaan dalam dunia pendidikan. Hal ini disebabkan oleh kajiankajian sosiolinguistik yang menghubungkan bahasa dengan fenomena sosial dan kultural. Misalnya tinjauan tentang variasi bahasa, tinjauan 
yang melihat bahasa dari konteks sosial yang sebenarnya. Selain itu sosiolnguistik juga berusaha mencari hubungan regular antara linguistik dan struktur sosial. (Bell, 1995:40)

Kalau dilihat motivasi awal perkembangannya, sosiolinguistik berusaha untuk menunjukkan adanya kovarian linguistik yang sistematis dan struktur sosial, bahkan barangkali juga menunjukkan adanya hubungan kausalitas antara keduanya. Sosiolinguistik adalah salah satu ilmu yang kan menjawab tentang masalah-masalah yang topiknya bisa dirumuskan sebagai berikut :

Pertama, Bahasa, Dialek dan Ragam Bahasa. Setiap penutur bahasa akan selalu berbahasa dengan satu aksen. Dengan demikian tidak bisa dikatakan bahwa seorang penutur memilki aksen, sedangkan penutur lain tidak memilki aksen. Aksen dibatasi pada deskripsi aspekaspek ucapan yang dapat menunujukkan dari mana penutur bahsa berasal, baik secara regional ataupun sosial. (Chaika, 1982:132). Aksen berbeda dengan dialek Dialek mengacu ke semua perbedaan antara variasi bahasa yang satu dengan yang lain mencakup penggunaan tata bahasa, kosakata, maupun aspek-aspek ucapan. Dialog juga dapat dibedakan menurut wilayah (dialek regional), menurut faktor-faktor kemasyarakatan (dilek sosial) dan waktu pemakaian dialek (dialek temporal). (Cahyono, 1995:387)

Kedua, Masyarakat Bahasa. Yang dimaksud dengan masyarakat bahasa adalah sekelompok orang yang merasa menggunakan bahasa yang yang sama (Chaer, 1994:60). Karena titik berat pengertian masyarakat bahasa pada merasa menggunakan bahasa yang sama, maka konsep masyarakat bahasa dapat menjadi luas atau menjadi sempit. Masyarakat bahasa bisa melewati batas propinsi, batas Negara bahkan juga batas benua.

Ketiga, Bilingualisme dan Multilingualisme. Kedwibahasaan (bilingualism) mengacu ke pemakaian bahasa leih dari satu bahasa oleh seseorang, kelompok atau Negara. Di dalam konsep kedwibahassan itu tercakup konsep kemultibahasaan (multilingualism) dalam scala kecil (micro-level) yang menyangkut individu atau kelompok kecil, dan dalam 
skala besar (macro-level) yang menyangkut masyarakat atau negara. Dalam kedwibahsaan berskala kecil terdapat seseorang yang menguasai dua bahasa (bilingual) atau lebih dari dua bahasa (multilingual). Dalam kedwibahasaan berskala besar terdapat masyarakat atau negara yang memakai satu bahasa atau monoglosia (monoglossic), dua bahasa (diglossic), dan lebih dari dua bahasa atau poliglosia (polyglossic),

Keempat, Penggunaan Bahasa (Etnografi Bahasa). Adanya berbagai macam dialek dan ragam bahasa menimbulkan masalah, bagaimana kita harus menggunakan bahasa itu dalam masyarakat. Seorang pakar sosiolinguistik yang bernama Hmes mengatakan, bahwa suatu komunikasi dengan menggunakan bahasa harus memperhatikan delapn unsure yang diakronimkan menjadi SPEAKING. (Chaer, 1994: 63). Kedelapan hal tersebut adalah: 1) Setting and Scene ( berkenaan dengan tempat dan waktu terjadinya percakapan), 2) Participants (orang yang terlibat dalam percakapan), 3) Ends (maksud dan hasil percakapan), 4) Act Sequences (bentuk dan isi percakapan), 5) Key (Cara dan semangat dalam melakukan percakapan), 6) Instrumentalities (Jalur percakapan), 7) Norms (norma prilaku peserta percakapan), dan 8) Genres (ragam bahsa yang digunakan).

Kelima, Perencanaan Bahasa. Pembakuan bahasa merupakan salah satu bentuk kerangka perencanaan bahasa yang bisa dilakukan oleh badan pemerintah yang resmi atau organisasi swasta. Bahasa baku adalah variasi bahasa yang menjadi dasar penulisan media masa dan buku-buku dan merupakan variasi bahasa yang diajarkan di sekolahsekolah. Bahasa baku memiliki 4 (empat) fungsi, yaitu: 1) fungsi pemersatu, 2) fungsi kekhasan, 3) fungsi pembawa kewibawaan, dan 4) fungsi sebagai kerangka acuan (Bambang, 1994:386)

Keenam, Bahasa dan Kebudayaan. Salah satu pertanyaan kebahasaan yang menarik dan mengundang perhatian ahli bahasa adalah: "Apakah terdapat hubungan anatara kemampuan penalaran suatu suku bangsa dengan bahasa asli yang dimiliki?". Dengan kata lain, "Apakah seorang penutur bahasa dari suku bangsa yang memiliki bahasatertentu 
memandang dunia yang sama secara berbeda dengan penutur bahasa dari suku bangsa yang lain?".

Selain itu, ada 3 (tiga) topik yang juga sangat penting dalam kajian sosiolinguistik, yaitu: 1) fungsi kemasyarakatan bahasa, 2) profil sosiolinguistik, dan 3) sikap bahasa.

\section{Urgensi Sosiolinguistik dalam Pembelajaran Bahasa}

Keberhasilan dan kegagalan pembelajaran bahasa terletak bada banyak faktor, seperti: tujuan pembelajaran, bahan pelajaran, sumber belajar, dana dan sarana, siswa, dan guru. Berikut diagram yang memuat faktor-faktor yang mempengaruhi keberhasilan pembelajaran:

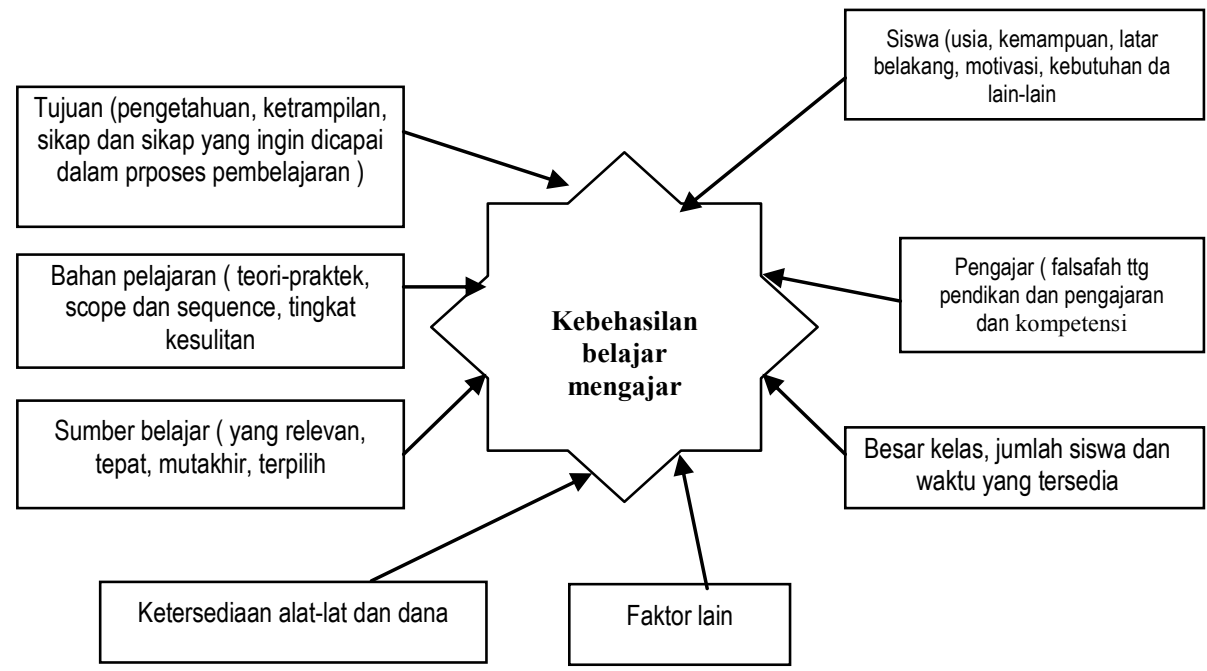

Dari diagram di atas, dapat dilihat adanya banyak faktor yang berpengaruh dan perlu dipertimbangkan dalam proses pembelajaran untuk mencapai hasil yang diinginkan, antara lain: 1) tujuan yang ingin dicapai, 2) materi pembelajaran, 3) sumber-sumber belajar, 4) keadaan siswa, 5) keadaan guru, 6) keadaan kelas, jumlah siswa dan waktu yang tersedia, 7) biaya dan lainnya.

Ketika kita memasuki dunia pembelajar bahasa, menurut H.H. Stern, berarti kita telah bergelut dalam 4 (empat) konsep utama 
pembelajaran bahasa, yaitu: 1) bahasa, 2) pembelajaran, 3) bahan ajar, dan 4) konteks (Parera, 1987:6). Berikut akan diurai keempat konsep itu guna melihat letak urgensitas sosiolinguistik dalam pembelajaran bahasa.

Pertama, Pembelajaran bahasa memrlukan konsep tentang hakekat bahasa. Secara implicit dan ekplisit seorang guru bahasa bekerja berdasar teori tentang bahasa. Pertanyaan pokok yang diajukan tentang teori pembelajaran bahasa adalah; "Apa sebenarnya bahasa dalam pembelajaran bahasa?". Pertanyaan ini dijawab linguistik, psikolinguistik dan sosiolinguistik

Kedua, Pembelajaran bahasa menuntut pandangan tentang pebelajar bahasa dan bahan ajar bahasa. Pertanyaan yang mendasar adalah: "Siapa yang sedang belajar bahasa dan bahan ajar apa yan paling tepat diberikan padanya?". Pertanyaan kedua ini akan dijawab oleh psikologi pendidikan, psikolinguistik dan sosiolinguistik.

Ketiga, Pembelajaran bahasa melibatkan guru dalam proses pembelajaran. pertanyaan mendasar atas hal ini adalah: "Bagaiman teori pembelajaran bahasa sebenarnya? Apa tugas dan peranan para guru dalam proses pembelajaran?". Pertanyaan ketiga ini akan dijawab oleh studi pendidikan

Keempat, Pembelajaran berlangsung dalam konteks tertentu. Pengertian tentang konteks merupakan bagian yang esensial dalam teori. Bahasa, belajar bahasa dan mengajar bahasa harus dilihat dalam konteks apa, bagaimana setting pendidikanya, dan apa latar belakang dilakukannya pembelajaran bahasa. Ada 2 (dua) hal penting yang harus dijelaskan dalam hal ini. Pertama, Konteks Bahasa. Bahasa pertama seorang pebelajar dan bahasa sasaran mengejewantahkan diri dalam konteks sosial, kultural dan politik tertentu yang termuat dalam pembelajaran bahasa. Dalam pengembangan teori pembelajaran bahasa, yang perlu dipersoalkan adalah dalam masyarakat seperti apakah bahasa itu diajarkan? Bagaimana dengan eksistensi sosiolinguistiknya? Pertanyaan semacam ini akan dijawab oleh sosiologi, sosiolinguistik. Kedua, Setting Pendidikan. Setiap pendidikan tentunya mempunyai seting 
tertentu( misalna pendidikan nasional). Pertanyaan yang bisa diajukan dalam masalah ini adalah: "Bagaimana posisi bahasa yang diajarkan (mislanya bahasa Arab) dalam pendidkan nasional? Bagaimana pembelajaran bahasa asing disesuaikan dengan konteks pendidikan yang khusus?". Pertanyaan ini memerlukan analisis pendidikan yang didukung oleh analisis sosiologi dan sosiolinguistik.

Membincang masalah ini, H.H. Stern mengembangkan model kebijakan dan proses pembelajaran bahasa dalam sekema (Parera, 1987:2) sebagai berikut:

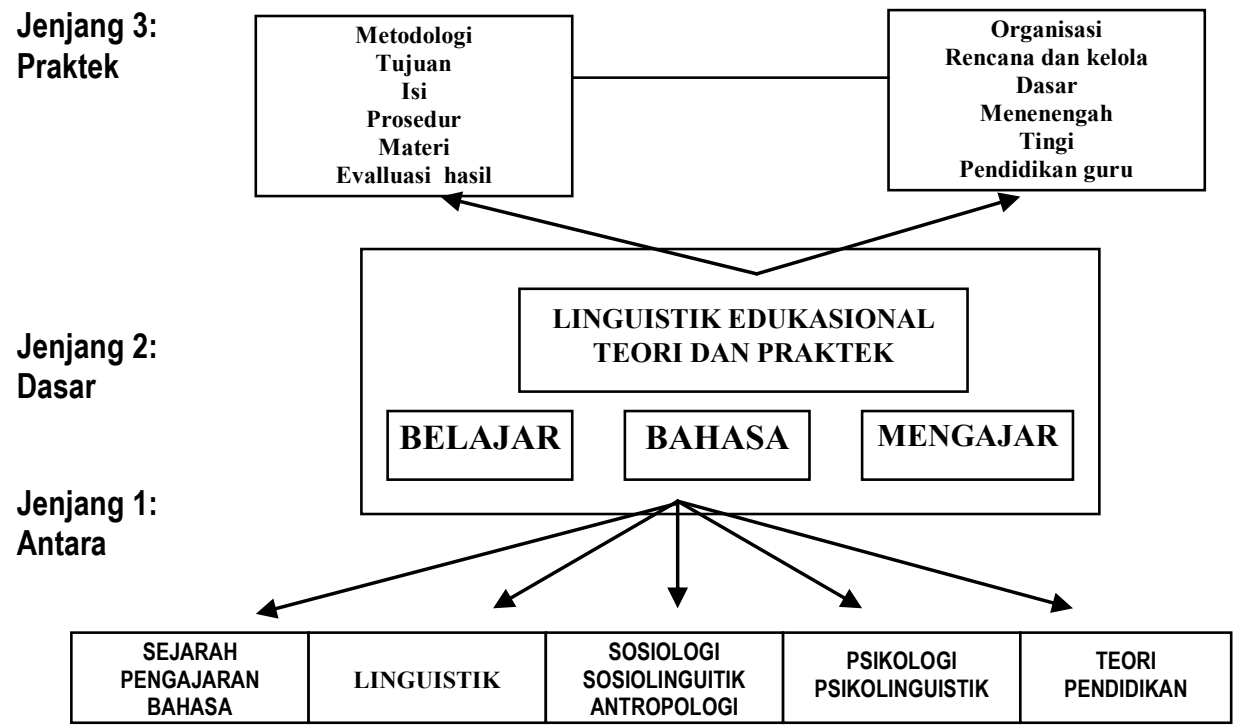

\section{Kontribusi Sosiolinguistik dalam Pembelajaran Bahasa}

Pembelajaran bahasa tidak dapat berlangsung dengan baik tanpa memanfaatkan jasa ilmu-ilmu lain yang relevan dengannya, seperti: psikologi, pedagogik, sosiologi, antropologi, manajemen, sosiolinguistik, psikolinguistik dan linguistik. 
Dilihat dari segi obyeknya, pembelajaran bahasa erat sekali hubungnnya dengan linguistik, akan tetapi bila dilihat dari beberapa segi yang lain keduanya menunujukkan beberapa titik perbedaan, terutama bila ditinjau dari segi tujuan, metode dan sikap. Titik perbedaan itu bisa terlihat dari uraian sebagai berikut:

Pertama, Tujuan. Linguistik bertujuan menemukan kriteria atau teori universal yang akan menerangkan fenomena bahasa, sedangkan guru bahasa bertujuan membantu murid menguasai bahasa. Kedua, Metode. Linguistik menggunakan metode formal dan abstrak, sedangkan guru bahasa menggunakan metode fungsional yang praktis. Ketiga, Sikap. Linguistik melihat bahasa sebagai suatu sistem sedangkan guru bahasa melilhat bahasa sebagai suatu ketrampilan. (Syahrudin, 1989:2).

Dengan adanya dua tendensi yang bersifat saling menjauhi antara dua hal yang kelihatan berbeda, tapi sangat bermanfaat untuk didekatkan, terasa penting cabang ilmu yang dikenal dengan nama linguistik terapan (applied Linguistik).

Linguistik terapan berusaha menjembatani yang ada antara teoritisi dan praktisi yang disebabkan oleh perbedaan sikap, metode dan tujuan kedua kelompok tersebut. Sebagai akibatnya, pada awal kemunculan ilmu ini, orang tidak bisa membedakan antara linguistik terapan dan pembelajaran bahasa (Syahrudin, 1989:3). Padahal, linguistik terapan tidak hanya pembelajaran bahasa saja.

Sosiolinguistik merupakan salah satu ilmu bahasa terapan yang mempelajari tentang problematika dialek suatu daerah, dialek suatu daerah dan juga topic bilingual dan multilngual (Shabri Ibrahim, 1995:5). Secara umum yang dimaksud dengan ilmu terapan adalah pemanfaatan ilmu pengetahuan untuk merencanakan dan membuat desain bagi kegiatan yang praktis dalam kehidupan sehari-hari. (Parera, 1987:10). Jika dikatakan sosiolinguistik sebagai ilmu linguistik terapan, itu berarti pemanfaatan ilmu sosiolinguistik untuk kepentingan proses pembelajaran bahasa . 
Pembelajaran bahasa pada suatu negara atau suatu daerah merupakan suatu keputusan politik, ekonomi dan sosial. Ini yang disebut kebijakan pengajaran bahasa. Apabila secara politis telah ditentukan, bahasa apa yang harus diajarkan, dan kepada siapa bahasa itu harus diajarkan, maka langkah selanjutnya adalah bahan apa yang harus diajarkan dan bagaimana cara mengajarkannya. Penjelasan ini bisa dilihat dalam bagan sebagai berikut:

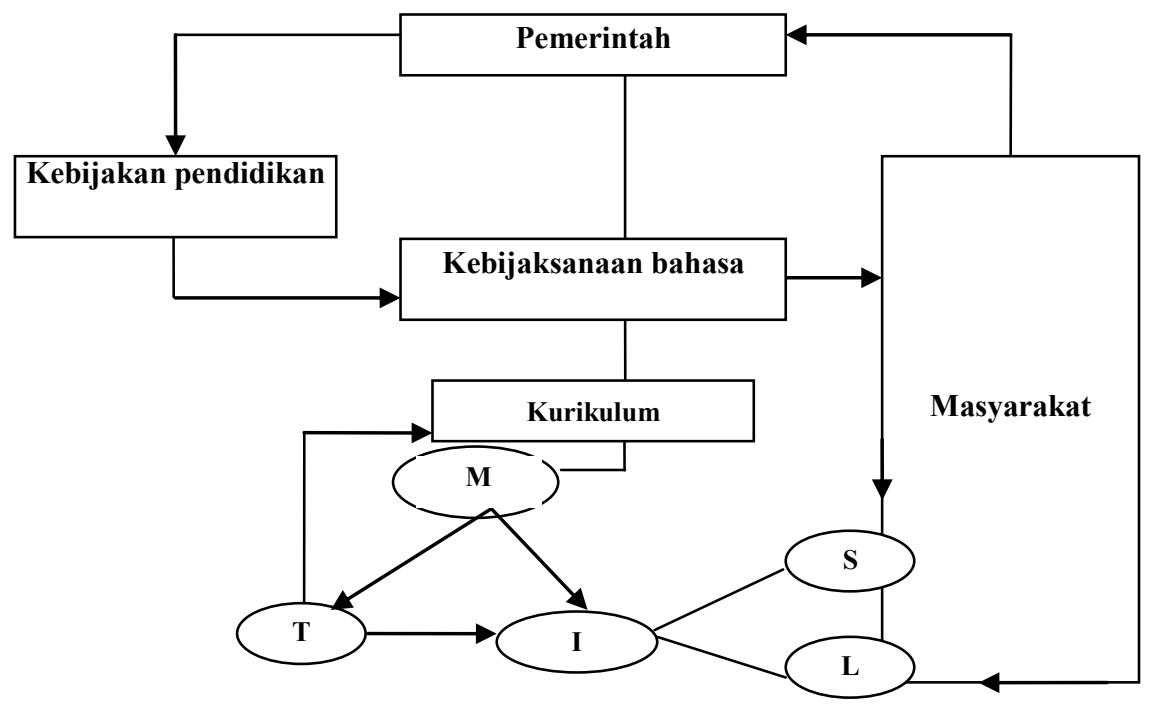

Keterangan :

$\mathrm{M}$ : metode dan variabel bahan

$\mathrm{T}$ : Variabel guru ( apa yang dibuat oleh guru)

I : Variabel instruks ( apa yang diperoleh pebelajar)

S : Variabel sosiokultural (apa dan bagaimana sikap lingkungan)

L : Variabel pebelajar (apa yang dilakukan pebelajar)

Para linguist tidak menjamin bahwa penemuan teoritis mereka akan berguna dalam pembelajaran bahasa. Hal ini tercermin dari kontroversi pendapat mereka tentang peranan teori linguistik dalam pembelajaran bahasa. Ada dua kubu yang saling bertentangan. Yang pertama kontra (baca: tidak setuju) dengan pendapat yang mengatakan 
bahwa teori mempunyai peranan dalam pembelajaran bahasa. Sedangkan yang kedua pro (baca: setuju) bahwa teori linguistik mempunyai peranan penting dalam pembelajaran bahasa. Pendapat pertama dipelopori oleh Robert Stokwell dan Sol saporta. Sedangkan yang kedua tokohnya adalah S.Pit Corder. (Wahab, 1998: 112-114)

Lepas dari kontroversi ini, melalui berbagai kajian menunjukkan bahwa sumber yang paling kuat dan tepat untuk menentukan silabus pembelajaran bahasa adalah linguistik (baik sebagai ilmu murni ataupun terapan). Kita akan bisa melihat kontribusi sosiolinguistik dalam pembelajaran bahasa dalam aplikasi linguistik yang dibagi menjadi 3 (tiga)tahap (Parera, 1989:11-13). Penjelasan dari tiga tahap tersebut adalah:

Tahap aplikasi pertama adalah tahap deskripsi linguistik. Tahapan ini memberi jawaban atas pertanyaan general tentang hakekat bahasa yang diajarkan. Tahapan ini tidak menjawab tentang apa yang akan diajarkan atau bagaimana suatu bahan akan disusun.

Gambaran dari aplikasi tahap pertama ini terlihat dalam bagan berikut :

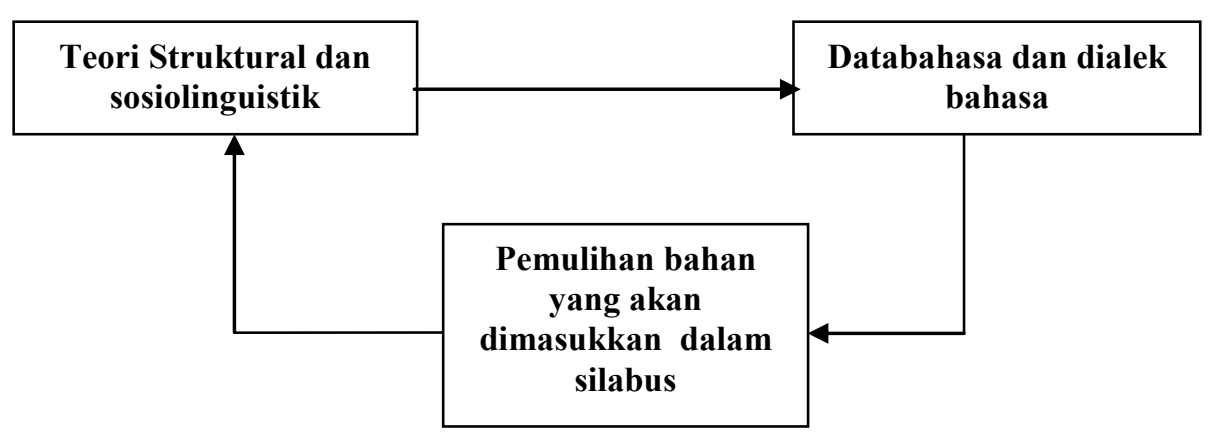

Tahap aplikasi kedua berhubungan dengan soal isi silabus. Kita tidak akan mengajarkan keseluruhan bahasa. Dalam tahapan ini kita akan melakukan disain hasil. Untuk itu akan dilakukan pemilihan bahan. Kriteria pemilihan bahan pembelajaran bisa bermacam-macam. Misalnya saja, manfaat bagi pebelajar, apa yang diperlukan pebelajar dalam kehidupan sehari-hari berkaitan dengan bahasa yang akan 
dipelajarinya, perbedaan antara bahasa ibu dan bahasa yang akan dipelajarinya, kesulitan apa yang dihadapi oleh pebelajaran bahasa asing pada umumnya dan sebagainya.

Aplikasi tahapan kedua ini tergambar dalam bagan berikut :

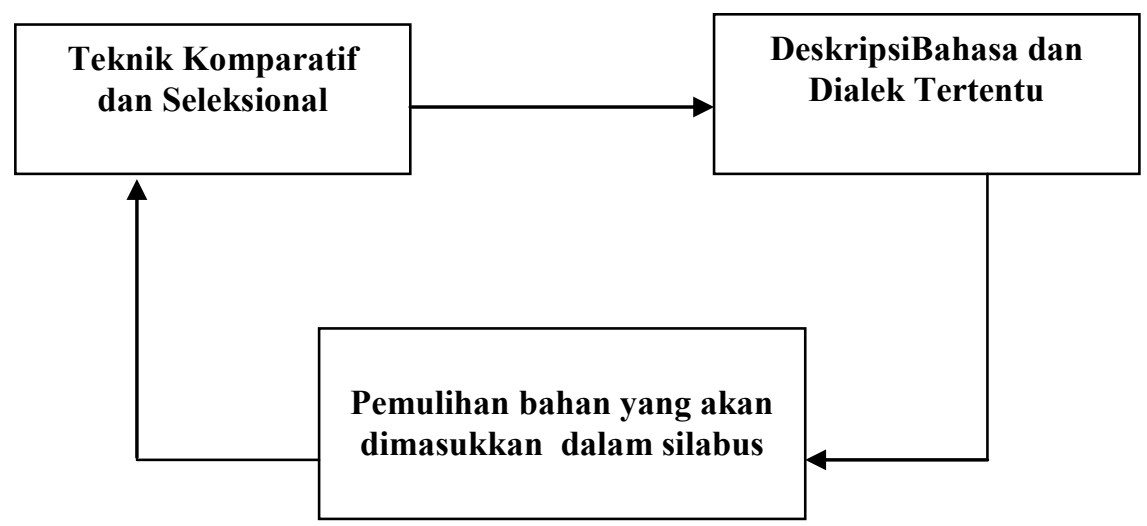

Tahap aplikasi ketiga merupakan tahap kegitan pembelajaran bahasa. Karena pada tahap kedua belum bisa membuat silabus yang lengkap dan utuh tentang bahsa, maka kaidah-kaidah penyusunan silabus ini perlu memperhatikan faktor linguistik, psikolinguistik ataupun sosiolinguistik.

Gambaran aplikasi ketiga bisa dilihat dalam bahan berikut : 


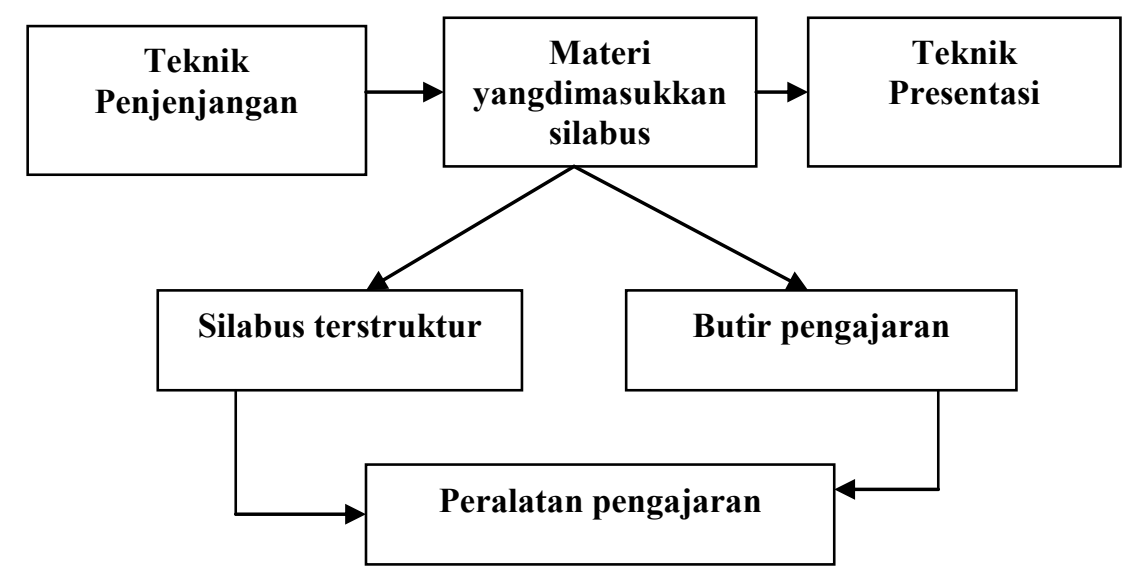

Operasi pembelajaran bahasa mencakup keseluruhan kegiatan pembelajaran bahasa; mulai dari perencanaan, persiapan, perbaikan, pembagian tugas dan evaluasi. Selain itu buku-buku ajar, sarana, silabus, waktu dan tempat, juga termasuk dalam operasional pembelajaran bahasa.

Operasional pembelajaran bahasa ditentukan secara hirarki oleh hal-hal yang tergambar dalam table berikut ini:

\begin{tabular}{|l|l|l|l|}
\hline Tingkat I & Politik & Pemerintah & $\begin{array}{l}\text { Bahasa apa, untuk siapa, } \\
\text { tingkat berapa }\end{array}$ \\
\hline Tingkat II & $\begin{array}{l}\text { Linguistik } \\
\text { sosiolinguistik }\end{array}$ & Linguistik terapan & $\begin{array}{l}\text { Apa yang diajarkan, berapa } \\
\text { lama diajarkan, berapa } \\
\text { banyak diajarkan }\end{array}$ \\
\hline Tingkat III & $\begin{array}{l}\text { Psikolinguistik } \\
\text { Pedagogik }\end{array}$ & Guru Kelas & $\begin{array}{l}\text { Bagaimana mengajarkan } \\
\text { materi yang telah ada }\end{array}$ \\
\hline
\end{tabular}

\section{Penutup}

Dari pembahasan di atas, tampak bahwa kontribusi sosiolinguistik dalam pembelajaran bahasa memang cukup signifikan terutama dalam memberikan informasi tentang hakekat bahasa dan pemilihan bahan ajar yang sesuai dengan konteks kemasyarakatan dan 
kondisi sosial pebelajar bahasa. Karena itu, tenaga edukatif yang bertugas sebagai pengajar bahasa, seharusnya memahami kajian teori lingustik yang meliputi ilmu-ilmu kebahasaan terutama ilmu-ilmu murni. Selain itu, ia juga memperdalam sosiolinguistik. Mengingat bahwa bahasa tidak bisa lepas dari gejala dan fenomena sosial yang dalam hal edukasi, pengajar bahasa perlu memahami tingkat sosial kebahasaan pada anak didiknya dan lingkungan tempat proses pembelajaran dan pemerolehan bahasa asing dilangsungkan. $\square$ 


\section{DAFTAR PUSTAKA}

Al-Sayid, Sabri Ibrahim. Tanpa tahun. Ilm al-lughah al-Ijtima' I. Beirut: Dar al-Ma'rifah al-Jami'iyyah.

Bell, Roger T. 1995. Sociolinguistic Goals, Approaches and Problems, Terj. Abdul Syukur Ibrahim. Surabaya: Usaha Nasional.

Cahyono, Bambang Yudi. 1995. Kristal-Kristal Ilmu Bahasa. Surabaya: Airlangga University Press.

Chaer, Abdul. 1994. Linguistik Umum. Jakarta: Rineka Cipta.

Chaika, Elaine. 1982. Language The Social Mirror. Rowley Massachusetts: Newbury House Published.

Parera, Jis Daniel. 1987. Linguistik Edukasiona : Pendekatan Konsep dan Teori Pengajaran Bahasa. Jakarta: Erlangga.

Wahab, Abdul. 1998. Isu Linguistik Pengajaran Bahasa dan Sastra. Surabaya: Airlangga University Press. 